Creative commons User License: CC BY-NC-ND

Abstracted by: EBSCOhost, Electronic Journals Service (EJS),

Google Scholar, Journal Seek, Scientific Commons,

Food and Agricultural Organization (FAO), CABI and Scopus
Journal of Agricultural Extension

Vol. 22 (1) February, 2018

ISSN(e): 24086851; ISSN(Print); 1119944X

http://journal.aesonnigeria.org

http://www.ajol.info/index.php/jae

Email: editorinchief@aesonnigeria.org

\title{
Environmental Factors Influencing Artisanal Fishing in Eastern Obolo Local Government Area of Akwa Ibom State
}

https://dx.doi.org/10.4314/jae.v22i1.6

\section{Ifeanyi-Obi, C.C.}

Department of Agricultural Economics and Extension, University of Port Harcourt, Rivers State, Nigeria.

Email: Clara.ifeanyi-obi@uniport.edu.ng; Phone: +2348033397055

Iremesuk, $\mathbf{P}$.

Department of Agricultural Economics and Extension, University of Port Harcourt, Rivers State, Nigeria.

Email: Praise.iremesuk@gmail.com; Phone: +2348160505363

\section{Abstract}

The study identified the environmental factors affecting artisanal fishing in Eastern Obolo local government area of Akwa Ibom state, Nigeria. Ninety artisanal fishermen were selected using two-stage sampling techniques. Questionnaire and interview schedule was used to get information. The research objectives were analyzed using frequency, percentages and mean. On the socioeconomics characteristics of the artisanal fishermen, it was found that the majority (58\%) of the respondents were male with $36 \%$ of the respondents having secondary school as their highest level of education. Also $31 \%$ have fishing experience of below10 years with yearly fish output of above $1000 \mathrm{~kg}$ by $31 \%$ of the respondents and yearly income of greater than N200,000 by $53 \%$ of the respondents while $81 \%$ belong to co-operative society. Extension agents have visited none of the respondents. The major environmental factors affecting artisanal fishing in the area were oil spillage (100\%), waste disposal (100\%) and climatic factors (100\%). On the constraints faced, the study found out that militant activities, inadequate finance, oil spillage around depots, and poor sales were found to be serious. Based on the findings of the study, it was recommended that, the Government and other appropriate authorities should enforce the fishing laws and regulations to avoid illegal exploitation of fishing grounds by trawlers and the destruction of artisanal fishing gears. Also, better access to relevant information should be enhanced by making extension services available to fish farmers in the various depots

Keywords: Artisanal, environmental, fishing, 
Creative commons User License: CC BY-NC-ND

Abstracted by: EBSCOhost, Electronic Journals Service (EJS),

Google Scholar, Journal Seek, Scientific Commons,

Food and Agricultural Organization (FAO), CABI and Scopus
Journal of Agricultural Extension

Vol. 22 (1) February, 2018

ISSN(e): 24086851; ISSN(Print); 1119944X

http://journal.aesonnigeria.org

http://www.ajol.info/index.php/jae

Email: editorinchief@aesonnigeria.org

\section{Introduction}

The existence of enormous water bodies offers great potentials for the development of the fishing industry in Nigeria. Fisheries development began in 1914 in Nigeria when the first fisheries office was established as a component of the Agricultural office of the colonial administration (Anko \&Eyo, 2003). According to Olomola (1998), artisanal fishery subsector accounts for over $80 \%$ of total fish output in Nigeria as evidenced by available data from the Federal Department of Fisheries. An artisanal, traditional or small scale fishery is used to characterize those fisheries that were mainly nonmechanized with low level of production (Matthew, 2001). They are the predominant fishery in tropical developing countries (Berkes, Mahon, McConney, Pollnac \& Pomeroy, 2007).

According to Inoni and Oyaide (2007), artisanal fisheries include coastal, brackish water and all inland fishery sources such as rivers, reservoirs, dams, lakes, lagoons as well as the floodplains of the Niger Delta and other major rivers. Ekpo and Essien-lbok (2013) noted that artisanal fishing is a major producer of fish for the teaming population of Akwa Ibom State and Nigeria at large though in the recent times, there has been a significant drop in the quantity of fish produced in the area.

Generally, artisanal fishing operation is tedious and characterized by low individual productivity. The problems faced by artisanal fishers in Nigeria are not far from what is experienced by artisanal fishermen in Eastern Obolo. Some of the problems faced by artisanal fish farmers in Eastern Obolo LGA according to Pro-Natura International (Nigeria) (2004) include lack of enforcement of fishing laws and regulation, illegal exploitation of the artisanal fishing grounds by trawlers, gas flares and oil spillage destroy nursery ground for fish breeding, Climate change, depletion of fish due to the use of dynamite and other obnoxious means to catch fish, use of the wrong type of nets by trawlers and fishermen, continuous increase in the price of fishing gears(FAO, 1986; Anko \& Eyo, 2003; IFAD, 1988; Ipinmoroti, 2012; Ekpo \& Nzegblue, 2012; Eyenihi,1990)

Fish farmers are also faced with attacks from sea pirates who seize their engines and most times there is the problem of claim of ownership which is ongoing in some fishing ports in Eastern Obolo Local Government Area presently.

From the on-going, it is evident that environmental and socio-economic factors influence artisanal fishing in the area.

Hence this research sought to answer the following questions:

i. What are the socio-economic characteristics of artisanal fish farmers in the study area?

ii. What are the socio-economic factors affecting the artisanal fish farmers?

iii. What are the environmental factors affecting the artisanal fish farmers? 
Creative commons User License: CC BY-NC-ND

Abstracted by: EBSCOhost, Electronic Journals Service (EJS),

Google Scholar, Journal Seek, Scientific Commons,

Food and Agricultural Organization (FAO), CABI and Scopus
Journal of Agricultural Extension

Vol. 22 (1) February, 2018

ISSN(e): 24086851; ISSN(Print); 1119944X

http://journal.aesonnigeria.org

http://www.ajol.info/index.php/jae

Email: editorinchief@aesonnigeria.org

iv. What are the constraints faced by the artisanal fish farmers?

\section{Objectives of the study}

The broad objective of the study was to assess the influence of environmental and socio-economic factors on artisanal fishing in Eastern Obolo Local Government Area of Akwa Ibom state. The specific objectives were to:

i. describe the socio-economic characteristics of the artisanal fish farmers;

ii. determine the socio-economic factors affecting artisanal fish farming;

iii. identify environmental factors affecting the artisanal fish farmers and

iv. examine constraints faced by artisanal fishermen in the study area.

\section{Hypothesis}

Ho1: There is no significant relationship between the artisanal fish farmer's socioeconomic characteristics and the constraints faced.

Ho2: There is no significant relationship between the artisanal fish farmer's socioeconomic characteristic and the environmental factors affecting their fishing activities

\section{Methodology}

The study was conducted in Eastern Obolo Local Government of Akwa Ibom state. Akwa Ibom State is one of the nine states of the Niger Delta region. It is located in the central Southern part of the country, lying between latitude $4^{\circ} 32^{\prime} \mathrm{N}$ and $5^{\circ} 33^{\prime} \mathrm{N}$, and longitudes $7^{\circ} 25^{\prime} \mathrm{E}$ and $8^{\circ} 25^{\prime} \mathrm{E}$. The State is bordered on the east by Cross River State, on the west by Rivers state and Abia State and on the south by the Atlantic Ocean and the southernmost tip of Cross Rivers State. The State consists of 31 local government areas with Uyo as the capital. It occupies a total land area of $7,081 \mathrm{~km}^{2}$ with a population of 3.92million people (National Population Census, 2006). According to Akwa lbom State Government online, Eastern Obolo is located in the Niger delta fringe between Imo and Qua lboe rivers estuaries and lies between latitude $4^{\circ} 28^{\prime}$ and $4^{\circ} 53^{\prime}$ and longitudes $7^{\circ} 50^{\prime}$ and $7^{\circ} 55^{\prime}$ east. It is bounded in the North by Mkpat Enin LGA, North East by Onna, and West by Ikot Abasi, South East by Ibeno LGA and in the South by the Atlantic Ocean. Eastern Obolo has a population of about 60,543 people (National Census, 2006) who are predominantly fishermen with over $85 \%$ involved in active fishing. Crop farming activities are also carried out in the local government with crops like cassava, maize, plantain, yam, citrus and pineapple. Eastern Obolo has a total landmass of $117008 \mathrm{~km}^{2}$ with an estimated shoreline of about $184 \mathrm{~km}$ long. Fishing is done at various fishing depot which include Educwink, Elekpon, Agan-asa.

The population of the study was made up of all artisanal fish farmers in Eastern Obolo local government of Akwa Ibom State. Two-stage sampling technique was used. Educwink, Eleponn and Agan-asa fishing depots were selected using purposive sampling. The fishing depots were selected because they were the only functional fishing depots presently in the study area as other depots were having communal 
Creative commons User License: CC BY-NC-ND

Abstracted by: EBSCOhost, Electronic Journals Service (EJS),

Google Scholar, Journal Seek, Scientific Commons,

Food and Agricultural Organization (FAO), CABI and Scopus
Journal of Agricultural Extension

Vol. 22 (1) February, 2018

ISSN(e): 24086851; ISSN(Print); 1119944X

http://journal.aesonnigeria.org

http://www.ajol.info/index.php/jae

Email: editorinchief@aesonnigeria.org

clashes. Thirty (30) fishermen were selected randomly from each fishing depot based on the list of fish farmers in the depot.

Questionnaire was used to collect data from the fishermen. Interview schedule was employed for those who were not literate enough to read and write. On the spot observation was also used to complement the questionnaire administration. Secondary data was gotten through the internet, text books, journal papers and other relevant sources. Objective one, two and three was analyzed using descriptive statistics namely: percentage and frequency counts. Objective four was captured with a five-point likert scale and analyzed using descriptive statistics: mean while the hypothesis was tested using ordinary least square regression analysis.

\section{Hypothesis}

Ho1: There is no significant relationship between the artisanal fish farmer's socioeconomic characteristics and the constraints faced.

Ho2: There is no significant relationship between the artisanal fish farmer's socioeconomic characteristic and the environmental factors affecting their fishing activities Both hypotheses were tested using Ordinary Least square regression analysis.

\section{Results and Discussion}

\section{Socio-economic characteristics of Eastern Obolo fish farmers}

Table 1 shows the socioeconomic characteristics of artisanal fish farmers in the study area. Table shows that the majority $(58 \%)$ of the respondents were male. This is an indication that males were more in artisanal fishing in the study area. This agrees with Okeowo, Bolarinwa and Ibrahim (2014) which revealed that males dominate artisanal fishing. The table further shows that $76 \%$ of the artisanal fish farmers were 50 years and below. This is an indication that majority of the proportion of the artisanal fish farmers in the study area were still in their active age. This agrees with the findings of Shettima, Mohammed, Ghide and Zindam (2014), which indicated that most of the fishermen were in their youthful age. The table also reveals that the majority (73\%) of the artisanal fish farmers were married. This indicates that many of them are saddled with family responsibilities and as such have the tendency of abandoning fish farming if enough financial proceed to take care of their family is not made from it. This also agrees with the findings of Okeowo et al., who revealed that majority of the respondents in Epe and Badagry were married. 
Creative commons User License: CC BY-NC-ND

Abstracted by: EBSCOhost, Electronic Journals Service (EJS),

Google Scholar, Journal Seek, Scientific Commons,

Food and Agricultural Organization (FAO), CABI and Scopus
Journal of Agricultural Extension

Vol. 22 (1) February, 2018

ISSN(e): 24086851; ISSN(Print); 1119944X

http://journal.aesonnigeria.org

http://www.ajol.info/index.php/jae

Email: editorinchief@aesonnigeria.org

Table 1: Percentage distribution of Eastern Obolo farmers according to socio-economic characteristics

\begin{tabular}{|c|c|}
\hline Variable & Percentage $(n=100)$ \\
\hline \multicolumn{2}{|l|}{ Gender } \\
\hline Male & 58 \\
\hline Female & 42 \\
\hline \multicolumn{2}{|l|}{ Age } \\
\hline Below 20 & 18 \\
\hline $21-30$ & 12 \\
\hline $31-40$ & 23 \\
\hline $41-50$ & 23 \\
\hline Above 50 & 24 \\
\hline \multicolumn{2}{|l|}{ Marital status } \\
\hline Single & 27 \\
\hline Married & 73 \\
\hline \multicolumn{2}{|l|}{ Highest level of education } \\
\hline No formal education & 27 \\
\hline Primary & 24 \\
\hline Secondary & 36 \\
\hline Tertiary & 13 \\
\hline \multicolumn{2}{|l|}{ Household size } \\
\hline Below 5 & 42 \\
\hline $6-10$ & 41 \\
\hline $11-15$ & 15 \\
\hline $16-20$ & 1 \\
\hline Above 20 & 1 \\
\hline \multicolumn{2}{|l|}{ Fishing experience } \\
\hline Below 10 & 31 \\
\hline $11-20$ & 26 \\
\hline $21-30$ & 28 \\
\hline $31-40$ & 7 \\
\hline Above 40 & 8 \\
\hline \multicolumn{2}{|l|}{ Fishing output } \\
\hline $0-400$ & 9 \\
\hline $401-600$ & 17 \\
\hline $601-800$ & 18 \\
\hline $801-1000$ & 25 \\
\hline Above 1000 & 31 \\
\hline \multicolumn{2}{|l|}{ Yearly income } \\
\hline Less than $\$ 50,000$ & 3 \\
\hline Equal to or more than $\$ 100,000$ & 18 \\
\hline \multirow{2}{*}{\multicolumn{2}{|c|}{ \#150,000 }} \\
\hline & \\
\hline$\# 200,000$ and above & 57 \\
\hline Co-operative membership & 81 \\
\hline Visit from extension agents & 0 \\
\hline
\end{tabular}

Source: Field survey 2016 
Creative commons User License: CC BY-NC-ND

Abstracted by: EBSCOhost, Electronic Journals Service (EJS),

Google Scholar, Journal Seek, Scientific Commons,

Food and Agricultural Organization (FAO), CABI and Scopus
Journal of Agricultural Extension

Vol. 22 (1) February, 2018

ISSN(e): 24086851; ISSN(Print); 1119944X

http://journal.aesonnigeria.org

http://www.ajol.info/index.php/jae

Email: editorinchief@aesonnigeria.org

Only $27 \%$ did not have any formal education, the remaining $73 \%$ had either primary, secondary or tertiary education. This is an indication that majority of the artisanal fish farmers are literate enough to adopt new technologies that can improve their fishing activities since education is known to increase farmers' tendency to adopt new technologies. The majority (58\%) of the artisanal fish farmers have household size of 5 persons and above. This is an indication that the farmers maintain moderate number of persons in their households. Table shows that $69 \%$ have fishing experience of 10 years and above. This indicates that majority of the artisanal fish farmers have stayed long enough in the enterprise to have acquired the necessary knowledge and skill involved in the fishing enterprise. Only $9 \%$ of the artisanal fish farmers have yearly fish output of $400 \mathrm{~kg}$ and below. The rest have more than $400 \mathrm{~kg}$. Only few proportion $(31 \%)$ produce above $1000 \mathrm{~kg}$. This shows that the majority of the farmers do not produce substantial quantity. A majority (53\%) of the fish farmers earn $\$ 200,000$ and above on yearly basis. This is an indication that many of them are still living below the poverty index. It was also shown in Table 1 that $81 \%$ of the artisanal fish farmers are members of co-operative. This indicates that a cordial relationship exists amongst the fish farmers and as such extension services if and when available would be easy. All (100\%) the artisanal fish farmers agreed that no extension agent has ever visited them. This is surprising as agricultural extension agent are supposed to extend their services to these group of farmers.

\section{Environmental factors affecting artisanal fishing in Eastern Obolo Local Government Area}

Table 3 shows the factors affecting artisanal fishing activities in Eastern Obolo Local Government Area of Akwa Ibom State. The table shows that all (100\%) the artisanal fish farmers were affected by oil spillage, waste disposal and climatic factors while $84 \%$ were affected by Sea level fluctuation and $70 \%$ were affected by water mineral composition. The Table further shows that $77 \%$ of the respondents were affected by other sea animals, $99 \%$ by the use of chemical for fishing and $53 \%$ by marine erosion along beaches.

Oil spillage is a major environmental factor affecting both agricultural and nonagricultural practices in most communities of Rivers State especially the riverine communities. Majority of the available lands in these rirverine communities cannot be used for agricultural purposes because of the high level of damage to soil resulting from oil spillage. This has exposed many rural poor families in these communities who depend majorly on agricultural activities to hunger and malnutrition. 
Creative commons User License: CC BY-NC-ND

Abstracted by: EBSCOhost, Electronic Journals Service (EJS),

Google Scholar, Journal Seek, Scientific Commons,

Food and Agricultural Organization (FAO), CABI and Scopus
Journal of Agricultural Extension

Vol. 22 (1) February, 2018

ISSN(e): 24086851; ISSN(Print); $1119944 X$

http://journal.aesonnigeria.org

http://www.ajol.info/index.php/jae

Email: editorinchief@aesonnigeria.org

Table 3: Environmental factors affecting their fishing activities in Eastern Obolo Local Government Area

\begin{tabular}{ll}
\hline Variable & Percentage $(\mathbf{n}=\mathbf{9 0})$ \\
\hline Affected by sea level fluctuation & 84 \\
Affected by oil spillage & 100 \\
Affected by climate factors & 90 \\
Affected by water mineral composition & 30 \\
Affected by other sea animals & 77 \\
Affected by waste disposals in depots & 100 \\
Affected by sand gathering activities & 40 \\
Affected by use of chemicals for fishing & 99 \\
Affected by marine erosion along beaches & 53 \\
\hline
\end{tabular}

Source: Field survey, 2016.

\section{Constraints Faced by Artisanal Fish Farmers in Eastern Obolo Local Government Area}

Table 4 shows the constraints faced by artisanal fish farmers in Eastern Obolo Local Government Area of Akwa Ibom State. The Table shows that out of the thirteen variables used to capture the constraints artisanal fish farmers face in the fishing activities only four were not seriously affecting the farmers namely; religious barriers, increased pressure on fisheries resources, lack of extension services and unfavorable union activities and levies.

Table 4: Constraints faced by artisanal fishermen in Eastern Obolo local government area

\begin{tabular}{|c|c|c|c|}
\hline $\mathbf{S} / \mathbf{N}$ & Factors & Standard deviation & Mean \\
\hline 1. & Religious barriers & 0.00 & 1.0 \\
\hline 2. & Conflict amongst farmers & 1.17 & $3.4^{*}$ \\
\hline 3. & Militant activities hinder fishing & 0.00 & $5.0^{*}$ \\
\hline 4. & Type of instrument & 0.99 & $3.2^{*}$ \\
\hline 5. & Shortage of man-power & 0.94 & $3.1^{*}$ \\
\hline 6. & Increased pressure on fisheries resources & 1.06 & 2.0 \\
\hline 7. & Inadequate finance & 0.77 & $4.6^{*}$ \\
\hline 8. & Poor storage facilities & 1.10 & $3.9^{*}$ \\
\hline 9. & Poor sales & 0.72 & $4.4^{*}$ \\
\hline 10. & Lack of extension services & 0.68 & 1.7 \\
\hline 11. & Oil spillage around depots & 0.00 & $5.0^{*}$ \\
\hline 12. & Unfavorable union activities and levies & 1.23 & 2.9 \\
\hline 13. & High cost of instruments & 1.05 & $3.8^{*}$ \\
\hline
\end{tabular}

- Serious. Source: Field survey, 2016. 
Creative commons User License: CC BY-NC-ND

Abstracted by: EBSCOhost, Electronic Journals Service (EJS),

Google Scholar, Journal Seek, Scientific Commons,

Food and Agricultural Organization (FAO), CABI and Scopus
Journal of Agricultural Extension

Vol. 22 (1) February, 2018

ISSN(e): 24086851; ISSN(Print); 1119944X

http://journal.aesonnigeria.org

http://www.ajol.info/index.php/jae

Email: editorinchief@aesonnigeria.org

The farmers do not even know what extension services are all about as they have never seen any extension agent around and as such do not appreciate the need and use of extension information to improve their fishing activities. Other factors including conflict amongst farmers, militant activities, type of instrument used, shortage of man power, inadequate finance, poor storage facilities, poor sales, oil spillage around depots and high cost of instruments was found to be affecting the farmers seriously.

Farmers complained that activities of oil companies around the area result in oil spillage which affects their fishing activities so much. They explained that this eradicate the aquatic animals in the sea and even make the water unhealthy for them to fish in. They also complained that the oil companies restrict them from fishing in some areas. This result was not totally in line with that of Shettima et al., who revealed that $24 \%$ of the respondents were constrained by breeze (wind), $14 \%$ of the fishermen indicated unavailability of fish during fishing as the constraint they faced in the study area. It was ranked second most important constraint by the respondents. The other constraints faced by the fishermen in the study area were unavailability of fishing equipment (20\%), lack of formal education (15\%) and insufficient fund (18\%) ranked fourth, fifth and sixth respectively.

\section{Relationship between the artisanal fish farmer's socio-economic characteristics and the constraints.}

Table 5 shows the result from Ordinary Least Square regression analysis to determine the relationship between the artisanal fish farmers' socio-economic characteristics and the constraints faced. 
Creative commons User License: CC BY-NC-ND

Abstracted by: EBSCOhost, Electronic Journals Service (EJS),

Google Scholar, Journal Seek, Scientific Commons,

Food and Agricultural Organization (FAO), CABI and Scopus
Journal of Agricultural Extension

Vol. 22 (1) February, 2018

ISSN(e): 24086851; ISSN(Print); 1119944X

http://journal.aesonnigeria.org

http://www.ajol.info/index.php/jae

Email: editorinchief@aesonnigeria.org

Table 5: Relationship between the artisanal fish farmer's socio-economic characteristics and the constraints faced.

\begin{tabular}{|c|c|c|c|c|}
\hline Variables & Linear & Semi-log & Exponential & Double log \\
\hline Constant & $\begin{array}{l}42.709 \\
(19.277)^{* * *}\end{array}$ & $\begin{array}{l}41.702 \\
(21.610)^{\star \star *}\end{array}$ & $\begin{array}{l}3.732 \\
(24.197)^{\star \star *}\end{array}$ & $\begin{array}{l}3.725 \\
(19.078)^{\star \star *}\end{array}$ \\
\hline Gender $\left(X_{1}\right)$ & $\begin{array}{l}0.584 \\
(0.908)\end{array}$ & $\begin{array}{l}0.649 \\
(0.480)\end{array}$ & $\begin{array}{l}0.009 \\
(0.433)\end{array}$ & $\begin{array}{l}0.018 \\
(0.576)\end{array}$ \\
\hline Age $\left(X_{2}\right)$ & $\begin{array}{l}0.308 \\
(2.03)^{* *}\end{array}$ & $\begin{array}{l}1.802 \\
(0.947)\end{array}$ & $\begin{array}{l}0.12 \\
(0.831)\end{array}$ & $\begin{array}{l}0.038 \\
(0.875)\end{array}$ \\
\hline Marital status $\left(X_{3}\right)$ & $\begin{array}{l}0.440 \\
(0.301)\end{array}$ & $\begin{array}{l}0.374 \\
(0.312)\end{array}$ & $\begin{array}{l}0.10 \\
(1.082)\end{array}$ & $\begin{array}{l}0.009 \\
(0.340)\end{array}$ \\
\hline $\begin{array}{l}\text { Educational } \\
\text { attainment }\left(X_{4}\right)\end{array}$ & $\begin{array}{l}-1.412 \\
(-2.110)^{\star *}\end{array}$ & $\begin{array}{l}-0.997 \\
(-1.032)\end{array}$ & $\begin{array}{l}-0.006 \\
(-0.580)\end{array}$ & $\begin{array}{l}-0.021 \\
(-0.944)\end{array}$ \\
\hline Household size $\left(X_{5}\right)$ & $\begin{array}{l}0.296 \\
(0.424)\end{array}$ & $\begin{array}{l}0.563 \\
(0.430)\end{array}$ & $\begin{array}{l}0.007 \\
(0.421)\end{array}$ & $\begin{array}{l}0.012 \\
(0.396)\end{array}$ \\
\hline Fishing experience $\left(X_{6}\right)$ & $\begin{array}{l}-3.31 \\
(-2.131)^{* *}\end{array}$ & $\begin{array}{l}-1.554 \\
(-1.266)\end{array}$ & $\begin{array}{l}-0.020 \\
(-1.069)\end{array}$ & $\begin{array}{l}-0.032 \\
(-1.133)\end{array}$ \\
\hline Fish output $\left(X_{7}\right)$ & $\begin{array}{l}0.632 \\
(1.127)\end{array}$ & $\begin{array}{l}2.649 \\
(1.227)\end{array}$ & $\begin{array}{l}0.014 \\
(1.069)\end{array}$ & $\begin{array}{l}0.057 \\
(1.143)\end{array}$ \\
\hline Income $\left(X_{8}\right)$ & $\begin{array}{l}-2.560 \\
(-1.926)\end{array}$ & $\begin{array}{l}-1.880 \\
(-0.929)\end{array}$ & $\begin{array}{l}-0.012 \\
(-0.829)\end{array}$ & $\begin{array}{l}-0.38 \\
(-0.815)\end{array}$ \\
\hline $\begin{array}{l}\mathbf{R}^{2} \\
\text { F-statistic (F-value) }\end{array}$ & $\begin{array}{l}0.58 \\
10.51\end{array}$ & $\begin{array}{l}0.289 \\
7.10\end{array}$ & $\begin{array}{l}0.354 \\
9.561\end{array}$ & $\begin{array}{l}0.295 \\
6.412\end{array}$ \\
\hline
\end{tabular}

Source: Field survey,2016.

${ }^{* * *} P \leq 0.1,{ }^{* *} P \leq 0.5$. The values in parenthesis are $t$-values.

The linear functional form was chosen as the lead equation based on the high value of $R^{2}$, number of significant coefficients, appropriateness of signs and highest F-value, $(\mathrm{F}=10.51 ; \mathrm{P} \leq 0.5)$. The coefficient of multiple determination $\left(R^{2}\right)$ value of 0.58 indicates that about $58 \%$ of the variation in the constraints faced in artisanal fishing could be explained by the explanatory variables while the remaining $42 \%$ was due to other factors not specified in the model. .

The coefficient of age $\left(X_{2}\right)$ correlated positively and significantly with the constraints faced in artisanal fishing. This could imply that older famers face more constraints in their fishing activities than the younger ones. This may not be surprising as older farmers who have passed their productive age are known to be physically weaker than younger ones and may find it more difficult to face the challenges in fishing activities. Educational attainment $\left(X_{4}\right)$ and fishing experience $\left(X_{6}\right)$ were negative and significant at $5 \%$ significant level. More educated farmers are known to possess more skill and knowledge to tackle challenges, adopt new technologies and adapt to changing environment. Also, farmers who have spent high number of years in farming activities 
Creative commons User License: CC BY-NC-ND

Abstracted by: EBSCOhost, Electronic Journals Service (EJS),

Google Scholar, Journal Seek, Scientific Commons,

Food and Agricultural Organization (FAO), CABI and Scopus
Journal of Agricultural Extension

Vol. 22 (1) February, 2018

ISSN(e): 24086851; ISSN(Print); 1119944X

http://journal.aesonnigeria.org

http://www.ajol.info/index.php/jae

Email: editorinchief@aesonnigeria.org

are known to have gathered more skill and knowledge to tackle challenges and constraint more vigorously than ones with less experience.

Furthermore, yearly income of the farmers was negatively significant at $10 \%$ probability level indicating that fish farmers who have more income are more equipped to employ improved practices that could lessen the constraints and challenges faced in their fishing activities.

Relationship between the artisanal fish farmer's socio-economic characteristic and the environmental factors affecting their fishing activities

Table 6 shows the result from Ordinary Least Square regression analysis to determine the relationship between the artisanal fish farmers' socio-economic characteristics and the environmental factors affecting their fishing activities.

Table 6: Relationship between the artisanal fish farmer's socio-economic characteristics and the environmental factors affecting their fishing activities.

\begin{tabular}{|c|c|c|c|c|}
\hline Variables & Linear & Semi-log & Exponential & Double log \\
\hline Constant & $\begin{array}{l}42.213 \\
(19.277)^{\star * *}\end{array}$ & $\begin{array}{l}0.3752 \\
(74.197)^{\star * *}\end{array}$ & $\begin{array}{l}3.725 \\
(84.078)^{\star \star \star}\end{array}$ & $\begin{array}{l}41.702 \\
(21.616)^{\star \star *}\end{array}$ \\
\hline Gender $\left(X_{1}\right)$ & $\begin{array}{l}0.308 \\
(0.333)\end{array}$ & $\begin{array}{l}0.009 \\
(0.433)\end{array}$ & $\begin{array}{l}0.018 \\
(0.576)\end{array}$ & $\begin{array}{l}0.649 \\
(0.480)\end{array}$ \\
\hline Age $\left(X_{2}\right)$ & $\begin{array}{l}0.584 \\
(0.908)\end{array}$ & $\begin{array}{l}0.012 \\
(0.831)\end{array}$ & $\begin{array}{l}0.038 \\
(0.875)\end{array}$ & $\begin{array}{l}1.802 \\
(0.947)\end{array}$ \\
\hline Marital status $\left(X_{3}\right)$ & $\begin{array}{l}0.440 \\
(1.076)\end{array}$ & $\begin{array}{l}0.010 \\
(1.082)\end{array}$ & $\begin{array}{l}0.009 \\
(0.340)\end{array}$ & $\begin{array}{l}0.374 \\
(0.312)\end{array}$ \\
\hline $\begin{array}{l}\text { Educational } \\
\text { attainment }\left(X_{4}\right)\end{array}$ & $\begin{array}{l}-0.301 \\
(-0.653)\end{array}$ & $\begin{array}{l}-0.006 \\
(-0.580)\end{array}$ & $\begin{array}{l}-0.021 \\
(-0.944)\end{array}$ & $\begin{array}{l}-0.997 \\
(-0.032)\end{array}$ \\
\hline Household size $\left(X_{5}\right)$ & $\begin{array}{l}0.296 \\
(0.424)\end{array}$ & $\begin{array}{l}0.007 \\
(0.421)\end{array}$ & $\begin{array}{l}0.012 \\
(0.396)\end{array}$ & $\begin{array}{l}0.563 \\
(0.430)\end{array}$ \\
\hline Fishing experience $\left(X_{6}\right)$ & $\begin{array}{l}-0.955 \\
(-1.741)\end{array}$ & $\begin{array}{l}-0.020 \\
(-1.606)\end{array}$ & $\begin{array}{l}-0.032 \\
(-1.133)\end{array}$ & $\begin{array}{l}-1.554 \\
(-1.266)\end{array}$ \\
\hline Fish output $\left(X_{7}\right)$ & $\begin{array}{l}0.632 \\
(1.127)\end{array}$ & $\begin{array}{l}0.014 \\
(1.069)^{*}\end{array}$ & $\begin{array}{l}0.057 \\
(1.143)\end{array}$ & $\begin{array}{l}2.649 \\
(1.227)\end{array}$ \\
\hline Income $\left(X_{8}\right)$ & $\begin{array}{l}-0.560 \\
(-0.926)\end{array}$ & $\begin{array}{l}-0.012 \\
(-0.829)\end{array}$ & $\begin{array}{l}-0.038 \\
(-0.815)\end{array}$ & $\begin{array}{l}-1.880 \\
(-0.929)\end{array}$ \\
\hline $\begin{array}{l}\mathbf{R}^{2} \\
\text { F-statistic (F-value) }\end{array}$ & $\begin{array}{l}0.290 \\
1.32\end{array}$ & $\begin{array}{l}0.35 \\
4.01\end{array}$ & $\begin{array}{l}0.21 \\
2.10\end{array}$ & $\begin{array}{l}0.23 \\
1.85\end{array}$ \\
\hline
\end{tabular}

Source: Field survey, 2016.

${ }^{* * *} \mathrm{P} \leq 0.1,{ }^{* *} \mathrm{P} \leq 0.5$. The values in parenthesis are t-values.

Table 6 shows the result of the Ordinary Least Square regression analysis determining the relationship between the artisanal fish farmers' socio-economic characteristics and 
Creative commons User License: CC BY-NC-ND

Abstracted by: EBSCOhost, Electronic Journals Service (EJS),

Google Scholar, Journal Seek, Scientific Commons,

Food and Agricultural Organization (FAO), CABI and Scopus
Journal of Agricultural Extension

Vol. 22 (1) February, 2018

ISSN(e): 24086851; ISSN(Print); 1119944X

http://journal.aesonnigeria.org

http://www.ajol.info/index.php/jae

Email: editorinchief@aesonnigeria.org

the environmental factors they experience: Semi-log functional form has the best result considering the coefficient of multiple determination and significance of variables. The F-value $(4.01 ; P \leq 0.5)$ was not significant. There is no significant relationship between the artisanal farmer's socio-economic relationship and the environmental factors affecting their fishing activities.

\section{Conclusion and Recommendations}

Militant activities, inadequate finance, lack of extension services, and oil spillage around depots were the factors affect artisanal fishing in Eastern Obolo local government area of Akwa Ibom State. These factors need to be addressed to improve productivity of artisanal fishing in Eastern Obolo local government area. There is need to enforce fishing laws and regulations to avoid illegal exploitation of fishing grounds by trawlers and the destruction of artisanal fishing gears and Small-scale fisheries should also be upgraded in National agendas. Better access to relevant information should be enhanced by making extension services available to artisanal fish farmers in the various depots.

\section{References}

Anko E. O. \& Eyo A. A., (2003). Development of Fish in Nigeria: Fisheries Development in Nigeria with Special Reference to Cross Rivers State. In: $16^{\text {th }}$ Annual Conference of the Fisheries Society of Nigeria (FISON), 303.

Berkes F., Mahon R., McConney P. A., Pollnas R. B., Pomeroy R. S. (2007): Managing Smallscale Fisheries; Alternative Directions and Methods. International Development Research Centre, Ottawa, Canada.

Ekpo F. E. \& Nzegblue E. C., (2012). Climate Change Impact and Adaptation Opportunities on Agricultural Production in Communities around Itu LGA, Akwa lbom State, Nigeria. International Journal of Environmental Science, 2(4).

Ekpo I. E. \& Essien-lbok M. A., (2013). Development, Prospects and Challenges of Artisanal Fisheries in Akwa Ibom State, Nigeria. International Journal of Environmental Science Management and Engineering Research, 2(3): 69-85.

Eyenihi U. K. (1990). Biological Conservation for Environmental Stability and Food Production. Trans. Nig. Soc. Boil. Conserve. 1:4-10.

FAO (1986). Report of the CECAF adhoc working group on demersal and shrimp resources of the Gulf of Guinea. CECAF series 86/36, 108.

Food and Agricultural organization (1993) B.P Satia. "Ten years of integrated Development of Artisanal Fisheries in West Africa." Technical Report No.

50 (FAO 1993). 
Creative commons User License: CC BY-NC-ND

Abstracted by: EBSCOhost, Electronic Journals Service (EJS),

Google Scholar, Journal Seek, Scientific Commons,

Food and Agricultural Organization (FAO), CABI and Scopus
Journal of Agricultural Extension

Vol. 22 (1) February, 2018

ISSN(e): 24086851; ISSN(Print); 1119944X

http://journal.aesonnigeria.org

http://www.ajol.info/index.php/jae

Email: editorinchief@aesonnigeria.org

Food and Agricultural Organisation (FAO) (2007). Building adaptive capacity to climate change policies to sustain livelihoods and fisheries. New direction in fisheries-A Series of policy briefs in fisheries developmentissues. 08:16.

International Fund for Agricultural Development (IFAD) (1988) Nigeria, Artisanal Fisheries Project Appraisal report. 61.

Inoni O.E. \& Oyaide W. J. (2007). Socio-Economic Analysis of Artisanal Fishing in the South Agro-Ecological zone of Delta State, Nigeria. Agricultura Tropica et Subtropica. 40(4):135.

Ipinmoroti O. (2012). Salvaging Fisheries Systems in the face of Climate change. In: Etim L. \& Oribhabor B. (Editors) Current Issues in Sustainable Tropical Agriculture. Faculty of Agriculture, University of Uyo, Uyo. 18: 167-175.

Ly, C.K. (1980) The role of the Akosombo dam on the Volta river in causing erosionincentral and eastern Ghana (West Africa). Mar. Geol. 37: 323-332.

Matthew S. (2001). Small-scale Fisheries Perspective on an Ecosystem-based Approach to Fisheries management paper presented at the Reykjavik Conference on ResponsibleFisheries in the Marine Ecosystem, Reykjavik, Iceland. Food and Agriculture Organisation, Rome.

Okeowo T.A., Bolarinwa J.B. and Ibrahim D (2014). Socioeconomic Analysis of Artisanal fishing and Dominant fish species in lagoon waters of EPE and Badagry areas of Lagos state.

Olomola A. S. (1998). Sources and Resolution of Conflicts in Nigeria Artisanal Fisheries. Society and Natural Resources. 11:121.

Pro-Natural International (Nigeria) (2004). Status Report on Community Natural Resources in Eastern Obolo LGA, Akwa Ibom State. A Participatory Rural Appraisal (PRA) Report by Natural Resources Advocacy Team.

Shettima B.G, Mohammed S.T., Ghide A.A. and Zindam P.L. (2014). Analysis of Socioeconomic Factors Affecting Artisanal Fishermen around Lake Alau, Jere local government area of Borno state, Nigeria. 